\title{
Uneven and combined development and unequal exchange: the second wind of neoliberal 'free trade'?*
}

\author{
Andreas Bieler \\ School of Politics and International Relations, University of Nottingham/UK \\ and \\ Adam David Morton \\ Department of Political Economy, University of Sydney/Australia
}

\begin{abstract}
With capitalist social relations emerging in a prior system of absolutist states in Europe, the outward expansion of capitalism through conditions of uneven and combined development became dependent on the existence of multiple political entities. States in turn are brought into relations of unequal exchange within the global economy. This article analyses the way in which current neoliberal 'free trade' policies are related to these fundamental capitalist dynamics, deepening further processes of uneven and combined development as well as unequal exchange.
\end{abstract}

Keywords: capitalist expansion, free trade, unequal exchange, uneven and combined development.

Andreas Bieler is Professor of Political Economy and Fellow of the Centre for the Study of Social and Global Justice (CSSGJ) in the School of Politics and International Relations, University of Nottingham, UK. He is author of The Struggle for a Social Europe: Trade Unions and EMU in Times of Global Restructuring (Manchester University Press, 2006) and co-editor (with Ingemar Lindberg) of Global Restructuring, Labour and the Challenges for Transnational Solidarity (Routledge, 2010). His personal website is http://andreasbieler.net and he maintains a blog on trade unions and global restructuring at http://andreasbieler.blogspot.co.uk

Adam David Morton is Professor of Political Economy in the Department of Political Economy at the University of Sydney, Australia. His research interests include state theory, the political economy of development, historical sociology and Marxism in their relevance to the study of modern Mexico. He is the author of Unravelling Gramsci: Hegemony and Passive Revolution in the Global Political Economy (Pluto, 2007) and Revolution and State in Modern Mexico: The Political Economy of Uneven Development (Rowman \& Littlefield, 2013 Updated Edition), which was awarded the 2012 Book Prize of the British International Studies Association (BISA) International Political Economy Group (IPEG). His runs the blog For the Desk Drawer at http://adamdavidmorton.com/.

Correspondence address:

Andreas Bieler, School of Politics and International Relations, University of Nottingham, Nottingham NG7 2RD, UK. E-mail: Andreas.Bieler@nottingham.ac.uk 
At the beginning of the twentieth century, Leon Trotsky observed the particular way Russia was integrated into the world economy. Responding to military pressures by advanced Western countries, Russia, still based on feudal social relations, had embarked on a policy of industrialisation with a focus on production related to military needs. Financed mainly by foreign capital, small, highly concentrated pockets of advanced industry were combined with traditional social forms of organisation in feudal Russia. These were the conditions of 'uneven and combined development' (Trotsky, 1906/2007, p.27; Trotsky, 1929/2007, p.196; Trotsky, 1932/2008, p.8). Trotsky's participant-witness analysis of Russia in the late-nineteenth and earlytwentieth century focused predominantly on the role of foreign lending and investment in the industrialisation of backward conditions. Capitalist expansion, however, through relations of uneven and combined development has also been pursued through so-called 'free trade' policies, used to open up other countries along these dynamics and integrate them into relations of unequal exchange. Uneven and combined development has experienced an increasing scholarly interest in recent years. This literature, however, has hardly attempted to engage with the role of 'unequal exchange' and how it might relate to its considerations. The purpose of this article is to engage these dynamics and begin to consider how unequal exchange in 'free trade' relations may be a key dynamic relating to overall processes of uneven and combined development. In the next section, we first discuss processes of uneven and combined development. Unequal exchange, in turn, is then dealt with in the second main section, before the specific role of 'free trade' is discussed. The conclusion briefly discusses the possibilities of labour's agency in view of these dynamics. 


\section{Uneven and combined development: caught up in catch-up?}

Recently, some of Trotsky's points on the relationship between uneven and combined development and capitalism as a mode of production have once again been taken up. On one hand, Justin Rosenberg understands uneven and combined development as a transhistorical phenomenon and, thus, as intrinsic to the historical process itself (Rosenberg, 2006, p.309). In accord with the argument of Hannes Lacher (2006) and Benno Teschke (2003), he emphasises that capitalism emerged in an already existing international states-system. Because this inter-societal plurality precedes capitalism, he argues, such a transhistorical notion is necessary to an understanding of geopolitics. 'The issue of the geopolitical cannot be fully grasped from within a theory of capital' (Callinicos and Rosenberg, 2010, p.171). Admittedly Trotsky (1929/2004, p.24) asserted that it is 'necessary to understand this unevenness correctly, to consider it in its full extent, and also to extend it to the pre-capitalist past'. For Rosenberg, this justifies stretching uneven and combined development as a transhistorical essence, reaching 'all the way back into the socio-ecological unevenness characterising the earliest forms of social existence' (Rosenberg, 2010, p.186). On the other hand, Alex Callinicos accepts the relevance of uneven and combined development beyond the capitalist historical period but argues that its concrete dynamic within a specific historical period cannot be understood without reference to the dominant mode of production (Callinicos and Rosenberg, 2010, p.176). Concurrent with Neil Smith (1984/2008, p.4) 'uneven development is the systematic geographical expression of the contradictions inherent in the very constitution and structure of capital' and thus unique to capitalism. If treated as a universal process, uneven and combined development can therefore be reduced to a triviality telling us very little about capitalism and capitalist restructuring (see Smith 2006, p.182). 
While the expansive dynamic of feudalism was driven by political accumulation, i.e. the conquering of new territories and people (Brenner, 1985b, p.238; Teschke, 2003, p.99), the specific economic pressures of competitiveness within capitalism as a mode of production can only be grasped through an understanding of the way exploitation is based on wage labour and the private ownership of the means of production. Robert Brenner, through a detailed focus on the organisation of social property relations, argues that it was in medieval England that capitalist social relations of production emerged first, based on a landlord/capitalist tenant/wage-labourer structure. This then led to a situation in which both landlord and tenant depended on the market for their social reproduction (Brenner, 1985a, p.46-9). Importantly, the specificity of this development was not linked to the emerging world market and the trade in luxury goods for mercantilist elites, but to the development of a unique domestic economy based on a growing mass market for cheap basic goods such as food stuffs and cotton cloth (Brenner, 2001, p.233; Wood, 2002a, p.82). 'This system was unique in its dependence on intensive as distinct from extensive expansion, on the extraction of surplus value created in production as distinct from profit in the sphere of circulation, on economic growth based on increasing productivity and competition within a single market - in other words, on capitalism' (Wood, 2002b, p.23). And it was this dependence, which infused a dynamic of competitiveness into the production system, leading to constant technological innovation and increasing specialisation of production methods first in agriculture, then within the wider production of the industrial revolution. It is this dynamic, which fuels the relentless search for higher profit levels and makes capitalism such a dynamic production system. However, the inner logic of capitalism in this relentless search for higher rates of profit also implies that there is an inner tendency towards crisis. While the constant search for higher profits through the 
introduction of new machinery and technology into the production process may be a logical thing to do for the individual capitalist, for capitalism as a whole it is disastrous. If all capitalists attempt to produce more goods at cheaper prices and with fewer workers, then eventually there will be a lack of demand for their products resulting in a crisis of overproduction. 'Individual capitalists, in short, necessarily act in such a way as to de-stabilise capitalism' (Harvey, 1982/2006, p.188).

As Rosa Luxemburg pointed out, in order to ensure a constant increase in the accumulation of surplus value, capital relies on bringing non-capitalist spaces into the capitalist social relations of production in an outward expansionary dynamic, creating hothouse conditions for capital accumulation in non-capitalist environments (Luxemburg, 1913/2003, p.338). Hence a focus therein on processes of primitive accumulation in dispossessing peasant producers to create a reserve of labour power in non-capitalist territories based on the wage system; on the role of the non-capitalist world in absorbing commodities and surplus value; and on how states are drawn into the credit system to offset crisis conditions whilst subject to foreign interventionist, militarist, and imperialist relations. Ray Kiely engages critically with Luxemburg's analysis of the outward dynamic of the capitalist mode of production. Historically, capitalist accumulation did not functionally depend on absorbing ever more noncapitalist space. Before World War I, for example, most capital was invested in, and trade took place between, industrialised countries (Kiely, 2010, pp.79-81). And yet, at the same time, it is a fact that capitalism did expand outwardly in encompassing the whole globe. Already in 1848 Marx and Engels wrote about how capital overcomes periodic crises 'on the one hand through the enforced destruction of a mass of productive forces; on the other through the capture of new markets and a more thoroughgoing exploitation of old ones' (Marx and Engels, 1848/1998, p.18). The enforced destruction of productive forces and a more intensive exploitation of existing 
capitalist social relations of production links to Kiely's emphasis on developments internal to industrialised countries. The capture of new markets, however, refers to Luxemburg's focus on outward expansion. In other words, we can summarise that while outward expansion is not the only way capital attempts to overcome crises, it is clearly one significant aspect to it.

In his discussions of uneven and combined development, Trotsky argued that backwardness in a general situation of unevenness can actually be an advantage. 'The privilege of historic backwardness — and such a privilege exists — permits, or rather compels, the adoption of whatever is ready in advance of any specified date, skipping a whole series of intermediate stages' (Trotsky, 1932/2008, p.4). The history of capitalist modernity expressed through conditions of uneven and combined development should not therefore be considered as an uninterrupted temporal sequence of stages. Added to the register of pathways to capitalist catch-up with England were instances of so-called 'bourgeois revolutions from above' in the cases of Germany, Italy, the United States, and Japan. The central feature of such bourgeois revolutions being the change brought about in the character of the state (Callinicos, 1989, p.160). Neil Davidson adds the example of Scotland to these instances of catchup, able to draw on England's earlier advances (Davidson, 2010, p.10). At the same time, though, he warns against generalising from the Scottish experience. 'No other country would ever complete the transition from feudal agriculture to capitalist industrialisation so quickly or completely. The moment was too brief, the result so uniquely decisive, for any theoretical generalisation from this experience to be possible' (Davidson, 2006a, p.13). In short, there are only a few examples of successful developmental catch-up, generally located in advanced capitalist spaces of the world economy. The more common forms of capitalist transition-in some cases 
as instances of passive revolution—in the post-colonial world were experienced as a blocked form of dependent development (see Morton, 2010, pp.315-20; Morton, 2011, pp.35-9).

Chinese economic growth with double digit levels of increased GDP, year-onyear, is very impressive. What this picture, however, overlooks is, first, that uneven and combined development as a key dynamic of capitalist social relations of production is not only taking place between countries and regions but also within countries (Davidson, 2010, pp.15-16). 'They may have adopted the most modern forms of technology, industrial organisation and scientific thought in certain areas, but most of society remains at a much lower level' (Davidson, 2006b, p.211). Hypermodern coastal regions are counterpoised to backward inland areas in China. Moreover, as for Gross National Income per head, for example, the gap between China and the U.S. is enormous. In 2010 , 'China's $\$ 4,260$ was only 9 percent of the U.S.'s $\$ 47,240$. In order, to close the per capita gap in 30 years, Chinese GDP per head would have to grow about 10 percent per year for three decades, or expand to nearly 18 times its current size in that period' (Hardy and Budd, 2011, pp.30-31). In short, developmental catch-up is the exception, while a continuation and extension of unevenness is the norm.

\section{Capitalist expansion and the dynamics of unequal exchange}

Samir Amin has investigated in detail the dynamics of uneven and combined development and how the related conditions of unequal exchange between countries can explain the limits of catch-up. Historically, he distinguishes two different periods in the outward expansion of capital, two different ways as to how peripheral spaces have been repeatedly integrated into the core of global capitalism. Initial efforts to offset the tendency of the rate of profit to fall revolved around: 1) enlarging markets 
and exploiting new regions where the rate of surplus value was higher than at the centre, i.e. the outward expansion of capitalism as discussed by Luxemburg; and 2) reducing the cost of labour power and of constant capital, i.e. internal developments within the industrialised countries as highlighted by Kiely. From within such arguments the 'fresh geographical extension of capitalism's domain' over peripheral spaces was established through the mechanism of primitive accumulation. 'The characteristic feature of primitive accumulation, in contrast to normal expanded reproduction, is unequal exchange, that is, the exchange of products whose prices of production, in the Marxist sense, are unequal' (Amin, 1976, p.187). Relations within the world capitalist system are thus marked by the extension of the capitalist market at the expense of precapitalist systems, enabling the absorption of the surplus, and increases in the average rate of profit (Amin, 1976, p.188).

In the age of monopoly capitalism since 1945, i.e. the current phase of capitalism for Amin, expanded reproduction is possible not necessarily by integrating non-capitalist spaces, but through restructuring the way in which peripheral spaces are integrated within the global political economy. Through the export of capital, forms of production were established in peripheral spaces enjoying the advantage of low-wage costs. The tendency to overcome the contradiction between the capacity to produce and pressures that reduce the rate of profit was shifted to the plane of the world capitalist system. Three important structural changes furthered conditions of uneven development in the period of monopoly capitalism: (1) transnational capital operating on a world scale; (2) advances in technology transferring centrality to ultra-modern branches of activity—atomic power, space research, electronics—rendering obsolete the classical modes of accumulation, characterised by increasing the organic composition of capital; and (3) the concentration of technological knowledge in transnational corporations (Amin, 1976, p.189). In relation to ultra-modern advances 
in technology, the uneven development of the global political economy thus gets a 'second wind' as peripheral spaces come to accept a new form of specialisation, emerging as producers of capital goods, but still lagging behind advanced capitalist centres (Amin, 1976, p.190). In these processes, the formation of monopolies and the exporting of capital changed the function of peripheral spaces of capitalism so that they ceased to export agricultural products only and became exporters of finished manufactured goods, the expression of capitalist development that was a result of investment of capital by advanced capitalist centres (Amin, 1976, pp.185-6). This export of capital, however, can never overcome the crisis tendency of capitalism completely. In centres of advanced capitalism, the export of capital gives rise to a return flow that exceeds it in volume so the excess surplus is absorbed in other ways, including military expenditure and state aid (Amin, 1976, pp.180-1).

The export of capital, while not enabling the surplus to be absorbed, serves to raise the rate of profit, since capital benefits from a rate of surplus value in the periphery that is higher than in its country of origin. But this transfer is largely concealed by the equalisation of the rate of profit on the world scale, which constitutes the essence of unequal exchange (Amin, 1976, pp.181).

It is here, then, that the significance of unequal exchange begins to enter the picture, despite that literature being too extensive to be addressed fully here. ${ }^{1}$ One result is a 'sectoral unevenness in productivity', based on the divergence of the organic composition of capital in peripheral spaces, when the capitalist mode of production has not taken hold of all the branches of production, as it has at the centres of capitalism, to result in sectoral differences that mark the principal aspect of unevenness in the so-called 'Third World' (Amin, 1976, pp.215, 217-18). 
'These unevennesses of productivity are often reflected in unequal rates of profit, but also in unequal rewards of labour, especially where sectors that do not belong to the capitalist mode are concerned, as is often the case with rural production. This price structure has, therefore, nothing rational about it from the standpoint of the needs of a growth organised in order to put an end to the historical lagging-behind—uneven between one sector and another-which is characteristic of the periphery' (Amin, 1976, pp.223-4).

Further, in order to counteract the law of the tendency of the rate of profit to fall, capital imports labour from abroad at a lower wage, reserving the most thankless tasks for this labour whilst depressing the labour market more generally. 'This additional immigrant labour force constitutes also a disguised transfer of value from the periphery to the centre, since the periphery has borne the costs of training this labour force' (Amin, 1976, p.362).

In sum, the continuity and intensification of different productivity rates between developed and developing countries and, thereby, unequal exchange, is ensured through the 'second wind' of uneven and combined development.

\section{The new 'free trade' agenda and uneven development}

So far in previous sections, it has been concluded that capitalist expansion has taken place through processes of uneven and combined development. Uneven development constituted in two different periods of capitalist expansion, in turn, has locked countries into relations of unequal exchange, furthering the transfer of surplus value 
from the periphery to countries in the core on the basis of different productivity rates. In this section, the focus is on the role of free trade in these processes.

In a liberal understanding of capitalist development, free trade is regarded as a win-win situation, a positive-sum game. As David Ricardo famously argued, if every country concentrates on producing and exporting what it is best at, i.e. on its comparative advantage, and imports all the other necessities, an optimum outcome with everybody benefiting will be the result (Kiely, 2007, pp.13-16). However, reality has unmasked the false promises of liberal economic thinking. Trade liberalisation has often implied deindustrialisation and import dependence. An analysis of the consequences of trade liberalisation in Africa and Latin America during the 1980s and 1990s, for example, reveals widespread job losses, increasing unemployment and declining wages in both continents (War on Want, 2009, pp.5-13). As Anwar Shaikh makes clear, rather than drawing on the notion of 'comparative advantage', it is necessary to refer to the concept of 'competitive advantage', when analysing the underlying dynamics of free trade.

There are no magic mechanisms that will automatically make all regions (nations) automatically equal. Indeed, persistent trade imbalances covered by foreign capital flows are the "normal" complement of international trade between unequally competitive trade partners. Thus, free trade does not make all nations equally competitive, as is argued within standard trade theory. Rather, it exposes the weak to the competition of the strong. And as in most such cases, the latter devour the former (Shaikh, 2007, p.57).

Historical evidence confirms that developed countries relied heavily on protectionism and did not abide by patent laws in their own development. 'They generally 
championed free trade only when it was to their economic advantage' (Shaikh, 2007, p.60). Market leaders, often in areas of new technology, have a competitive advantage and are, therefore, interested in 'free trade' and 'open competition'. Developing countries, on the other hand generally operate in 'old industries'. So-called 'free trade' intensifies these imbalances in trade and production (Kiely, 2007, p.18).

Immanuel Wallerstein has linked unequal exchange to 'free trade'. Unequal exchange is considered to be the result of the appropriation of surplus value by countries in core capitalist spaces from countries in peripheral capitalist spaces on the basis of monopoly production.

When exchange occurs, competitive products are in a weak position and quasi-monopolised products are in a strong position. As a result, there is a constant flow of surplus-value from the producers of peripheral products to the producers of core-like products. This has been called unequal exchange (Wallerstein, 2004, p.28).

The key problem, however, is the way unequal exchange has been grounded within a definition of capitalist social relations of production linked to world-systems analysis. World-systems analysis explains the emergence of capitalism through a 'commercialisation model' of capitalism based on market relations. Instead of focusing on the way production is organised on the basis of wage labour, the emphasis is on production for profit in a market (Wallerstein, 1974, p.399). As a result, world-systems analysis resides within a circulationist logic or in the political relations of distribution (Brenner, 1977; Teschke, 2003, p.139).

In order to understand the dynamics of capitalism, the focus has to be instead on the social relations of production. Similar to Amin's focus on productivity differentials above, Ernest Mandel has also outlined how it is not the difference in the 
nature of the goods that is the cause of unequal exchange, but rather the difference in the productivity of labour that is decisive (Mandel, 1975, pp.66, 359, 368). Of course, a monopoly position of a product also implies that the labour productivity of workers producing this particular product is very high. Nevertheless, 'monopoly is one source of surplus profits, but much more important is technological innovation that, by increasing productivity, reduces the innovator's costs of production below the sectoral average' (Callinicos, 2010, p.23). A monopoly ensures the longer feasibility of higher productivity rates, but it is not in itself the cause of unequal exchange. Hence, 'on the world market, the labour of a country with a higher productivity of labour is valued as more intensive, so that the product of one day's work in such a nation is exchanged for the product of more than a day's work in an underdeveloped country' (Mandel, 1975, pp.71-2). Different productivity rates, in turn, are however the result of historical uneven development. This confirms Shaikh's understanding that unequal exchange is the result of uneven development, but not its cause. 'Since uneven development on a world scale is a direct consequence of free trade itself, these transfers of value and the theories of unequal exchange which rely on them emerge as secondary phenomena, not primary causes, of underdevelopment' (Shaikh, 1980, p.57). As a result, it can be concluded that 1) capitalism in its 'free trade' form in itself is a cause of uneven development and 2) free trade, in causing uneven and combined development, locks countries into further relations of unequal exchange.

Free trade has been a key aspect in the uneven and outward extension of capitalist social relations of production. As Kiely remarks, the British empire of the nineteenth century - the first period of capitalist outward expansion in Samir Amin's understanding — can be understood as a case of 'free trade' imperialism. 'What is very useful about the concept of 'free trade' imperialism is that it demonstrates how more 
developed capitalist countries can exercise power over less developed ones, largely through "economic relations" (although these are always backed by state regulation)' (Kiely, 2010, p.51). The post-World War II era, Amin's second phase, was then characterised by the further expansion of trade in manufactured goods through successive rounds of agreements on lowering taxes within the framework of the General Agreement on Tariffs and Trade (GATT). Then, the GATT Uruguay round of negotiations, between 1986 and 1994 expanded the agenda of 'free trade' significantly (see Introduction to this volume). First, it culminated in the establishment of the World Trade Organisation (WTO) in 1995, which also included a strengthened dispute settlement procedure facilitating the monitoring and enforcement of agreements. Moreover, the GATT Uruguay agreement also included the Agreement on Trade-Related Aspects of Intellectual Property Rights (TRIPs), a General Agreement on Trade in Services (GATS) as well as an Agreement on Trade-Related Investment Measures (TRIMs). "The successive expansion of the area of "free trade" has constituted a movement from the classical international trade of material goods . . - to far-reaching liberalisation and deregulation and, subsequently, neoliberal reregulation of the economy' (Patomäki and Teivainen, 2004, p.73). The WTO Doha round of negotiations, launched in 2001, was intended to deepen this expansion of the 'free trade' agenda further and complete 'unfinished business' especially in the area of services and public procurement but also agriculture. Due to increasing resistance to these developments, the WTO Doha negotiations have stalled. This does not mean, however, that the 'free trade' strategy has halted. In view of the problems at the multilateral level, both the European Union (EU) and the United States have increasingly engaged in bilateral strategies of 'free trade' agreements. These strategies include the expanded trade agenda and are a tool to achieve what has been impossible within a multilateral setting (Choudry, 2010). In other words, the expanded trade 
agenda including now also intellectual property rights, investment and services, initiated by the WTO and pursued through bilateral channels, is yet another way of integrating peripheral spaces into the global political economy in order to ensure the continued accumulation of surplus value in core spaces of advanced capitalism through unequal exchange, while deepening the prevailing spatial conditions of uneven development.

One noticeable example in this area is the EU's Global Europe strategy, launched in 2006 (Hilary, 2014). 'This openness is no longer simply about tariffs. Securing real market access in the twenty-first century will mean focusing on new issues and developing tools of trade policy to achieve the types of opening that make a real difference' (European Commission, 2006, p.6). Public services have been especially singled out as an area where the EU intends to open up new markets. 'Services are the cornerstone of the EU economy. They represent 77 percent of GDP and employment, an area of European comparative advantage with the greatest potential for growth in EU exports' (European Commission, 2006, p.8). By opening up developing countries to high productivity service corporations, some form of 'development' will result but the question to pose is for whom? as the old problem of combining elements of advanced technological progress with the lagging effects of older backward elements remains. As a result, processes of uneven and combined development are further extended while peripheral capitalist spaces become locked into new relationships of unequal exchange. Peripheral capitalist space is yet again transformed in the latest extension of the capitalist social relations of production through the 'second wind' of 'free trade', which is perhaps now entering a third phase of capitalist expansion beyond the two periods identified by Amin, which is to be discussed in the conclusion. 


\section{Conclusion}

This article has attempted to sketch the relationship between capitalist outward expansion linked to processes of uneven and combined development and relations of unequal exchange in order to assert the particular role of 'free trade' in these processes. Capitalist production, organised around wage labour and the private ownership of the means of production, is characterised by a crisis tendency. Outward expansion around uneven and combined development is thereby a key dynamic as to how such crises are overcome, albeit temporarily. Because capitalist expansion has historically taken place within an already existing international states-system, state spaces have become locked into relations of unequal exchange, in which surplus is transferred from peripheral spaces to advanced capitalist spaces due to different productivity rates. This outward expansion, as Amin reminds us, has taken place in several successive phases, reconstituting these relations of unequal exchange in new ways. So-called 'free trade' has always played an important role in the outward expansion of capitalism. Initially, non-capitalist spaces provided new markets to absorb surplus goods from centres of advanced capitalism. During the second phase, GATT negotiations facilitated further trade in manufactured goods. It is, however, the most recent period, in which the trade agenda has expanded, reaching into areas of financial investment and service provision, thereby adopting its most significant role. This situation heralds a new, third period reconstituting the relationships of unequal exchange between spaces of the global political economy as a result of continuing and intensified uneven development. It is these dynamics around the expanded free trade agenda, which Kiely refers to as a new phase of neoliberal, free trade imperialism (Kiely, 2010, p.188). It is these structuring conditions, with which labour movements around the world are today confronted. 
The implications for labour and its potential agency of resistance against further restructuring are complex. Precisely because capitalist expansion has been uneven, labour movements in different state spaces find themselves in contrasting locations within the global political economy. Already in the 1970s, Mandel remarked that 'it is hard to deny that American workers participated to a certain degree in the benefits of U.S. imperialism's monopoly of advanced industrial productivity (technology)' (Mandel, 1970, p.25). Thus, while some labour movements may feel that further capitalist expansion is in their interest and albeit only at first sight, others realise the detrimental impact the expanded 'free trade' agenda implies. When Trotsky analysed the way Russia was integrated into the global political economy through processes of uneven and combined development at the beginning of the twentieth century, he wanted to understand the structural preconditions of the Russian situation and in what way it may facilitate revolutionary upheaval (Trotsky, 1929/2004, p.152). The element of combined development is crucial in this respect, since it brings together the most advanced social forms with backward social forms, resulting in unstable state spaces, forming an explosive situation (Davidson, 2010, p.13). States supervising military-bureaucratic regimes of passive revolution in peripheral spaces, therefore, are potentially a more fertile ground for revolutionary uprisings than states in advanced capitalist centres (Cox, 1983, p.171; Davidson, 2010, pp.17-18). Increasing numbers of labour strikes in China and the collective power of opposition forces in public spaces such as Tahrir Square in Cairo, Syntagma Square in Athens and Taksim Square in Istanbul are testimony to such an understanding of the situation.

Additionally, we need to take into account the new, transnational organisation of the social relations of production as indicative of globalisation. Transnational production sectors, which bring workers from different state spaces together in one 
production process, may provide fertile ground for actions of transnational solidarity. Public services, on the other hand, continue to be predominantly organised at the national level. Nevertheless, the threat of privatisation and liberalisation as part of the new 'free trade' agenda affects them all in similar ways. Unsurprisingly, the Public Services International, the trade union organising public sector workers at the international level, has been very active in co-operation with other social movements in the resistance to neoliberal restructuring (Bieler, 2012, pp.374-6). The latter especially also includes resistance against the extended 'free trade' agenda through work in networks such as Our World Is Not For Sale (http://ourworldisnotforsale.org/, 25 July 2012). As forewarned with striking contemporary resonance by Rosa Luxemburg, capital in its attempts to ensure surplus accumulation through outward expansion is also continuing to undermine its very own conditions of reproduction, whether that is in the form of global war, ecological disaster, and/or rising discontent. Capitalism, 'becomes a string of political and social disasters and convulsions, and under these conditions, punctuated by periodical economic catastrophes or crises, accumulation can no longer go on' (Luxemburg, 1913/2007, p.447). It is the very challenge of developing non-capitalist spaces and pathways out of crisis that now necessitates further transnational solidarity.

\section{Notes}

\footnotetext{
* Paper presented at the workshop on 'Trade Unions, Free Trade and the Problem of Transnational Solidarity' at the Centre for the Study of Social and Global Justice (CSSGJ), University of Nottingham (2-3 December 2011). We are indebted to the workshop participants and two anonymous reviewers for their constructive comments on previous drafts.

${ }^{1}$ See, for example, Emmanuel 1972 and, for a critical engagement with Emmanuel, Shaikh 1979, 298-99
} 


\section{References}

Amin, S. (1976) Unequal Development: An Essay on the Social Formations of Peripheral Capitalism, trans. B. Pearce (New York: Monthly Review Press).

Bieler, A. (2012) "Workers of the world, unite?" Globalisation and the quest for transnational solidarity, Globalizations, 9(3), pp. 365-78.

Brenner, R. (1977) The Origins of Capitalist Development: A Critique of NeoSmithian Marxism, New Left Review I, 104, pp.25-92.

Brenner, R. (1985a) Agrarian Class Structure and Economic Development in PreIndustrial Europe, in T.H. Aston and C.H.E. Philpin (eds) The Brenner Debate: Agrarian Class Structure and Economic Development in Pre-Industrial Europe (Cambridge: Cambridge University Press), pp.10-63.

Brenner, R. (1985b) The Agrarian Roots of European Capitalism, in T.H. Aston and C.H.E. Philpin (eds) The Brenner Debate: Agrarian Class Structure and Economic Development in Pre-Industrial Europe (Cambridge: Cambridge University Press), pp.213-327.

Brenner, R. (2001) The Low Countries in the Transition to Capitalism, Journal of Agrarian Change, 1(2), PP.169-241.

Callinicos, A. (1989) Bourgeois Revolutions and Historical Materialism, International Socialism, Second Series, I, 43, pp.113-71.

Callinicos, A. (2010) Does Capitalism Need the State System?, in Alexander Anievas (ed.) Marxism and World Politics: Contesting Global Capitalism (London: Routledge), pp.13-26.

Callinicos, A. \& Rosenberg, J. (2010) Uneven and Combined Development: The Social-Relational Substratum of "the international"? An Exchange of Letters, in Alexander Anievas (ed.) Marxism and World Politics: Contesting Global Capitalism (London Routledge), pp.158-88.

Choudry, A. (2010) Fighting FTAs, Educating for Action: The Challenges of Building Resistance to Bilateral Free Trade Agreements, Journal of Alternative Perspectives in the Social Sciences, 2(1), pp.281-308.

Cox, R. W. (1983) Gramsci, Hegemony and International Relations, Millennium: Journal of International Studies, 12(2), pp.162-75

Davidson, N. (2006a) From Uneven to Combined Development, in H. Radice \& B. Dunn (eds) 100 Years of Permanent Revolution: Results and Prospects (London: Pluto Press), pp.10-26.

Davidson, N. (2006b) China: Unevenness, Combination, Revolution?, in H. Radice and B. Dunn (eds) 100 Years of Permanent Revolution: Results and Prospects (London: Pluto Press), pp.211-29.

Davidson, N. (2010) From Deflected Permanent Revolution to the Law of Uneven and Combined Development, International Socialism, Second Series, I, 128, http://www.isj.org.uk/?id=686

Emmanuel, A. (1972) Unequal Exchange: A Study of the Imperialism of Trade, trans. B. Pearce (New York: Monthly Review Press).

European Commission (2006) Global Europe - competing in the world. A contribution to the EU's Growth and Jobs Strategy, http://trade.ec.europa.eu/doclib/docs/2006/october/tradoc_130376.pdf

Hardy, J. \& Adrian, B. (2011, September) China's Capitalism in the Aftermath of the 2008 Crisis, Paper presented at the $11^{\text {th }}$ conference of European Sociological Association, Geneva, Switzerland.

Hilary, J. (2014) 'European trade unions and free trade: between international solidarity and perceived self-interest', Globalizations, 11(1). 
Kiely, R. (2007) The New Political Economy of Development: Globalization, Imperialism, Hegemony (London: Palgrave).

Kiely, R. (2010) Rethinking Imperialism (London: Palgrave).

Lacher, H. (2006) Beyond Globalization: Capitalism, Territoriality and the International Relations of Modernity (London: Routledge).

Luxemburg, R. (1913/2007) The Accumulation of Capital, trans. A. Schwarzschild (London: Routledge).

Mandel, E. (1970) The Laws of Uneven Development, New Left Review I, 59, pp.1938.

Mandel, E. (1975) Late Capitalism (London: New Left Books).

Marx, K. \& Friedrich, E. (1848/1998) Manifesto of the Communist Party, in Mark Cowling (ed.) The Communist Manifesto: New Interpretations (Edinburgh: Edinburgh University Press), pp.14-37.

Morton, A. D. (2010) Approaching Passive Revolutions, Capital \& Class, 36(3), pp. 315-42.

Morton, A. D. (2011) Revolution and State in Modern Mexico: The Political Economy of Uneven Development (Lanham, MD.: Rowman \& Littlefield).

Patomäki, H. \& Teivainen, T. (2004) A Possible World: Democratic Transformation of Global Institutions (London: Zed Books).

Rosenberg, J. (2006) Why is there no International Historical Sociology?, European Journal of International Relations, 12(3), pp. 307-40.

Rosenberg, J. (2010) Basic Problems in the Theory of Uneven and Combined Development. Part II: Unevenness and Political Multiplicity, Cambridge Review of International Affairs, 23(1), pp.165-89.

Shaikh, A. (1979) Foreign Trade and the Law of Value: Part I, Science and Society, 43(3), pp.281-302.

Shaikh, A. (1980) Foreign Trade and the Law of Value: Part II, Science and Society, 44(1), pp.27-57.

Shaikh, A. (2007) Globalization and the myth of free trade, in A. Shaikh (ed.) Globalization and the Myths of Free Trade: History, theory, and empirical evidence (Routledge, New York, NY), pp.50-68.

Smith, N. (1984/2008) Uneven Development: Nature, Capital and the Production of Space, Third edition (Athens, GA: University of Georgia Press).

Smith, N. (2006) The Geography of Uneven Development, in B. Dunn and H. Radice (eds) 100 Years of Permanent Revolution: Results and Prospects (London: Pluto Press), pp.180-95.

Teschke, B. (2003) The Myth of 1648: Class, Geopolitics, and the Making of Modern International Relations (London: Verso).

Trotsky, L. (1906/2007) Results and Prospects, in Leon Trotsky, The Permanent Revolution \& Results and Prospects. With introductions by M. Löwy (London: Socialist Resistance), pp.24-100.

Trotsky, L. (1929/2007) The Permanent Revolution, in Leon Trotsky, The Permanent Revolution \& Results and Prospects. With introductions by M. Löwy (London: Socialist Resistance), pp.111-256.

Trotsky, L. (1932/2008) History of the Russian Revolution (Chicago: Haymarket Books).

Wallerstein, I. (1974) The Rise and Future Demise of the World Capitalist System: Concepts for Comparative Analysis, Comparative Studies in Society and History, 16(4), pp. 387-415. 
Wallerstein, I. (2004) World-Systems Analysis: An Introduction (Durham: Duke University Press).

War on Want (2009) Trading Away Our Jobs: How free trade threatens employment around the world, http://www.waronwant.org/attachments/Trading\%20Away\%200ur\%20Jobs.pdf

Wood, E. M. (2002a) The Question of Market Dependence, Journal of Agrarian Change, 2(1), pp. 50-87.

Wood, E. M. (2002b) 'Global Capital, National States', in M. Rupert and H. Smith (eds.) Historical Materialism and Globalization (London: Routledge), pp.17-39. 